Studia UBB \$耳igitalia, Volume 62 (LXII) 2017, December, Issue 2, 25-34

Published Online: 2017-12-30

DOI:10.24193/subbdigitalia.2017.2.02

\title{
The story of the first electronic computer in Hungary
}

\author{
Balint Domolki \\ John von Neumann Computer Society \\ IT History Forum
}

\begin{abstract}
After several preparatory activities in the early 50 s, the Hungarian Academy of Sciences decided that it is necessary to have an electronic computer in Hungary. The Research Group for Cybernetics was established in mid-1956 and charged with the task of obtaining one. As commercial solutions proved to be impossible at that time it was decided to build the clone of a recently developed Soviet computer. The M-3 was a medium sized member of one of the first families of Soviet computers. Complete documentation and a package of key components were received in the framework of scientific cooperation. (Similar clones were built in Tallinn, Beijing, Erevan and M-3 was later manufactured in Minsk) Building of the M-3 started late 1957 (with the author's participation). Some life-signs were emerging in 1959, while more-or-less stabile operation was reached in 1960. Several improvements were made over the original design. Magnetic drum memory was exported to Timisoara for MECIPT. Despite its low performance, M-3 was successfully used to solve many real-life problems both for scientific-engineering calculations and in mathematical economics. Applications in other fields, like linguistics started too. The most important contribution of $\mathrm{M}-3$ was its role in educating computer experts: many of the future leading personalities - both on the development and on the application side - got acquainted with computing around the M-3. M-3 served academic computing until 1965, extended with three more years at Szeged University. In the first part of the 60 s commercial computers started to arrive to Hungary both from the USSR and the West.
\end{abstract}

Keywords: computing history, computers and education, Hungarian scholars 


\section{Prehistory in Hungary}

Computing in Hungary started ... in a prison! In the 50s in Hungary - like in many other countries of the Eastern bloc - many people were put in prison based on fabricated charges. Among these political prisoners, there were many high-level scientists and engineers. Sometimes they were working in an "engineering bureau" within the prison, making translations and even some design work. For this reason, they had a rather good access to Western literature (maybe better, than their colleagues "outside"). So, in late 1953 a group of inmates, having read about the developments of computing in the Western world, convinced the prison management to write a letter to the Hungarian Academy of Sciences, proposing to build a digital electronic computer. They offered to prepare the design and suggested academic institutions, where implementation can be made, with their "remote assistance". (A photocopy of the letter is published in [1]).

The letter got a politely negative answer, in early 1954, however, the Presidium of the Hungarian Academy of Sciences made a decision to establish within one of the academic research institutions a research unit "to study the building of high capacity computing machines in our country". Moreover, when in 1955 many political prisoners were rehabilitated, Rezső Tarján, one of the authors of the "letter from the prison" became the head

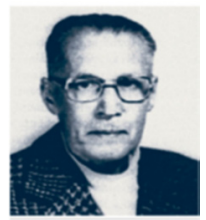

Rezsỗ Tarján (1908-1978) of this research unit.

In this capacity Tarján made a lot of efforts to promote the idea of electronic computing, by publishing articles, giving lectures, organizing meetings about early experiences with computers in the developed countries. This missionary work was helped by academician László Kalmár, who was the first among Hungarian mathematicians to recognize the significance of modern computing.

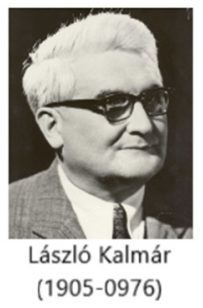

In January 1956 came an academic decision about the "necessity of purchasing high-speed digital computers from the Soviet Union", followed by government approval in September 1956 of the proposal of the Academy to establish Research Group on Cybernetics of the Academy, "with the main task of obtaining and operating an electronic digital computer." This approval, however, was on condition, that director of the group will be not Tarjan, but a high-level Party official Sándor Varga.

This - seemingly outrageous - decision had some merits, as it turned out later, that Varga was an experienced technical manager, with a successful track record in the Soviet (military) industry, and he had very valuable connections in Soviet industrial and academic circles.

The first action of the research group (in the following will be called KKCS according to the Hungarian acronym) was to place an order for a Ural computer from the USSR. The order was confirmed by the relevant Soviet foreign trade organization 
and delivery was foreseen in the 1957 plan of Soviet-Hungarian commerce. Due to the political situation in Hungary, KKCS could not start its actual work in 1956 and in early 1957 received a letter from the Soviet foreign trade organization about withdrawing from the deal, refusing to deliver the Ural computer to Hungary. Now, the connections of Varga proved to be useful: he succeeded in arranging to receive - in the framework of scientific cooperation with the Academy of Sciences of the USSR - the complete documentation together with a package of key components of a newly developed Soviet computer, the M-3.

Let us see now what this M-3 computer was about.

\section{Prehistory in the Soviet Union}

Academician I. S. Bruk ([2]:pp.61-64 and [3]) was a leading expert of analog computers since the late 30s. After the war his attention turned to digital computers, becoming popular in the West. In early 1948 a young assistant B. I. Rameev ([2]: pp.123-134 and [4]) joined his institute, being interested in digital computers. They developed the complete design of an electronic digital computer and submitted an invention application for the

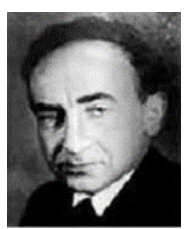

I.S. Bruk (1902-1974) "The Automatic Digital Computer" and received notarized Invention Certificate No. 10475 on December 4, 1948 - the first computer invention document in the Soviet Union (Nowadays in Russia the "Day of Informatics" is celebrated on December 4).

Another important early event was in 1949 the creation of the Special Constructor Bureau 245, established as the first (deeply secret) computer development organization (Order signed by J.V. Stalin!). This became the cradle of the Soviet computer industry (Rameev later became one of its key

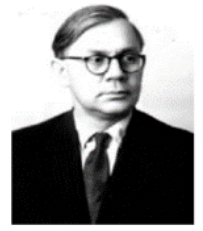

B.I. Rameev (1918-1994) personalities).

In the meantime, the Bruk group continued the implementation of the computer design mentioned above and in 1951 launched the M-1 [5], which is considered the first computer in Russia (practically the same time the computer MESM, developed by the group of S.A. Lebedev, was launched in Kiev, being considered the first computer in the Soviet Union).

The $\mathrm{M}-1$ had several thousand semiconductor devices and only 730 vacuum tubes. This significantly reduced size of the computer, which occupied a room as small as 15 square meters. It used two-address command system, a magnetic drum, widescreen TTY output and transmitter for their input from a punched tape. The number of bits - 25 . 
Internal memory on electrostatic tubes for 256 words and a magnetic drum for another 256. Performance was 20 operations per second. Operations: addition, subtraction, multiplication, division and several auxiliary operations. Power consumption - $8 \mathrm{~kW}$.

Computer "M-1" was used to calculate operation mode of electrical networks in Moscow, heating of ballistic missiles during the motion in the atmosphere, and for a number of projects of the Institute of Atomic Energy.

As the continuation of the "M" series, the computer M-2 [6] was developed in 1952-53. It had words of 34 bits and a 3-address instruction set, with a speed of 2000 floating point operations/sec. The internal storage devices included the main electrostatic device (standard cathode-ray tubes) that held up to 512 numbers and had regeneration cycle of $25 \mu \mathrm{s}$, plus an additional magnetic drum that held up to 512 numbers and rotated at 2860 revolutions/min. (A ferrite core memory of 4096 words was added in 1956). The external storage device - a magnetic tape drive - held up to 50 thousand numbers. Data was input from a punched tape reader and output to a teletypewriter. The total number of electronic tubes was 1879, including 203 in the power supply.

M-2 was a real workhorse of early Soviet computing, operating through 15 years performing calculations in atomic energy, missile design and in other scientific areas.

In 1955-1956 Bruk created the concept of small computers based on experience in building of the computers "M-1" and "M-2". As a result, the computer M-3 [7] was designed with the following main technical characteristics:

- electronic vacuum tube computer (800 tubes in 3 large cabinets)

- magnetic drum memory storing 1024 words of 31 bits.

- two-address instruction set, with a speed about 30 operations per sec.

(Later the storage was extended with a ferrite core memory and the speed improved to about $1500 \mathrm{op} / \mathrm{sec}$ )

The basic units of M-3 were:

- Arithmetic unit: four registers (31 bit)

- Address register (12 bit)

- Instruction counter (12 bit)

- Code control (6 bit + logical circuits)

- Storage- and i/o controllers

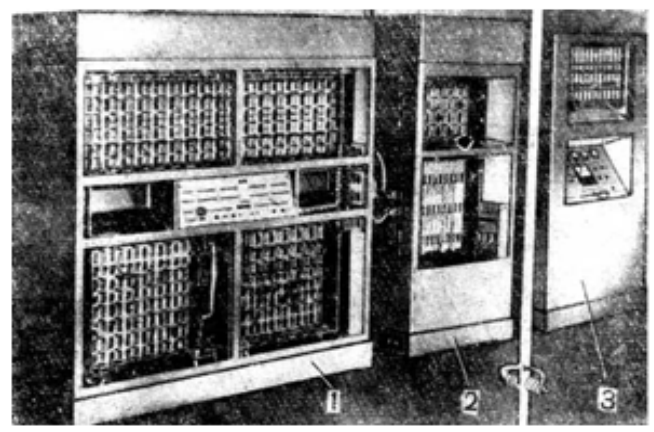

The structure of the two-address commands can be seen in the following diagram: 


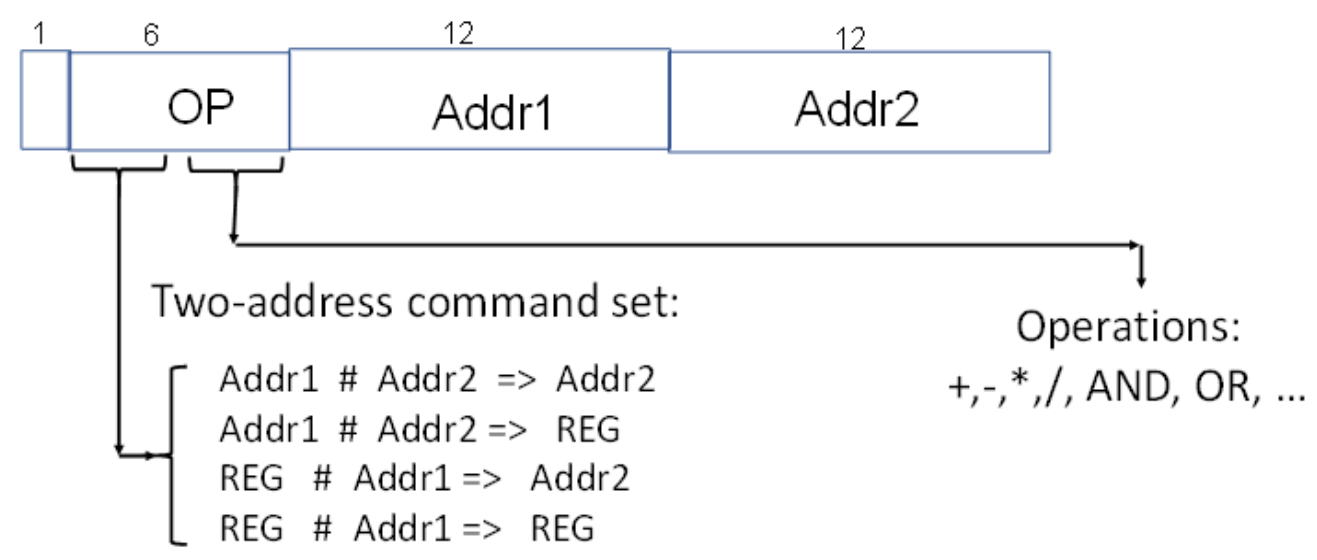

Development of the M-3 was completed in 1956, led by N.J. Matyukhin ([2]:pp.78-84 and [8]). Acceptance test by a state committee followed, passing with success in all technical parameters. Some bureaucratic problems did, however, arise: it turned out that the development of M-3 was performed as a kind of "over the plan" activity, not completely covered by the necessary paperwork. State committee acceptance was therefore delayed, serial

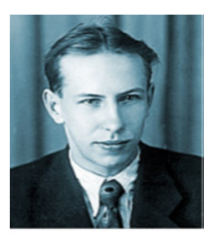

N.J.Matyukhin (1927-1984) production could not begin. The intermediate ("ex-lex") period was utilized by the developers to distribute the design of M-3 through informal academic channels.

This window of opportunity was seized by Varga in 1957, making use of his wartime personal contacts in Soviet academic and industrial circles. Apart from Hungary, building of (clones of) M-3 did fertilize early computer life in a few more countries, like China, Estonia and Armenia (where it served as starting point for the design of the successful Razdan family in Erevan). Finally, serial manufacturing started in the newly built computer factory in Minsk (Belorussia) from 1959, followed soon by the rather popular series of Minsk computers.

This - rather adventurous - offspring of the oldest family of Russian computers was the one we started to build in Hungary in 1958.

\section{Building of the $M-3$}

KKCS started actual work in mid-1957. Received premises in downtown Budapest in an office building of the Hungarian Academy of Sciences.

Recruitment of staff started in the Summer of 1957 with mainly freshly graduated electrical engineers and mathematicians (including the author). There were a few "adults" too, among them a couple of contributors of the "prison letter". A small number of workers in a mechanical workshop were employed to build the cabinets and the 
rather sizable cooling system. Young girls in the electrical workshop were preparing the circuits and did the wiring of the frames. By October 1957 the number of employees of the KKCS was 34.

Packets from USSR started to arrive in November-December, containing detailed technical documentation, and a large number of critical components (tubes, diodes etc.). Actual building work started in early 1958 and by the Autumn more or less everything was physically ready and in place.

One of the hardest technical problems was to design and manufacture the magnetic drum, with solving the problem of galvanizing of its surface. This was done so well, that magnetic drums were even exported to Timisoara (Romania) for the MECIPT computer (This was the very first export activity in the history of the computer field in Hungary).

Having a physically complete computer, now we had to "breathe life" into it. This was done first by independently calibrating and debugging the circuits and the basic units. After this, the complex testing of the whole computer would follow.

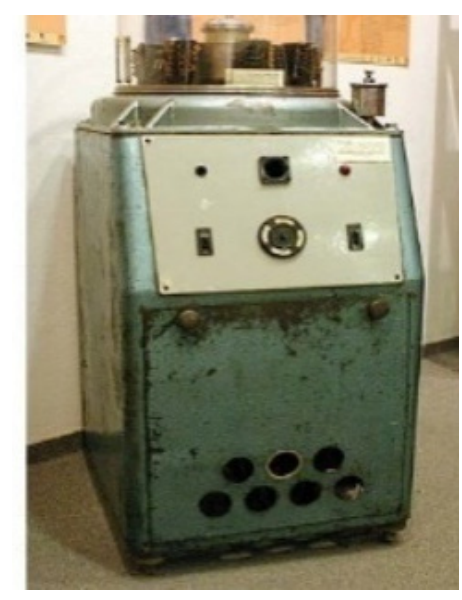

A big difficulty was, however, experienced here: The purely technical documentation did explain the circuits and wiring only, but not the operation of the computer, the execution of the instructions. So, the (tiresome) activity to discover the "architecture" of the computer had to be performed. As none of the engineers had previous knowledge about computers (this was not yet on the curricula of the universities at that time), one of the young mathematicians (the author) was charged with this task, as a "puzzle solving" activity. As a result, we succeeded to describe the operation of the computer with the help of a specially designed graphic language, showing to the engineers at each measuring point the waveform to appear in case of the correct operation.

This helped debugging and by the end of 1958 some life-signs were shown by the M-3: individual instructions and even short programs

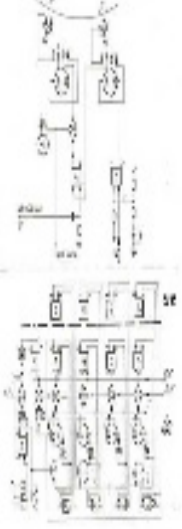
were - sometimes - executed. This resulted in a press announcement about readiness of M-3 on January 19, 1959 (with a report in the daily newspaper "Esti Hírlap"). 


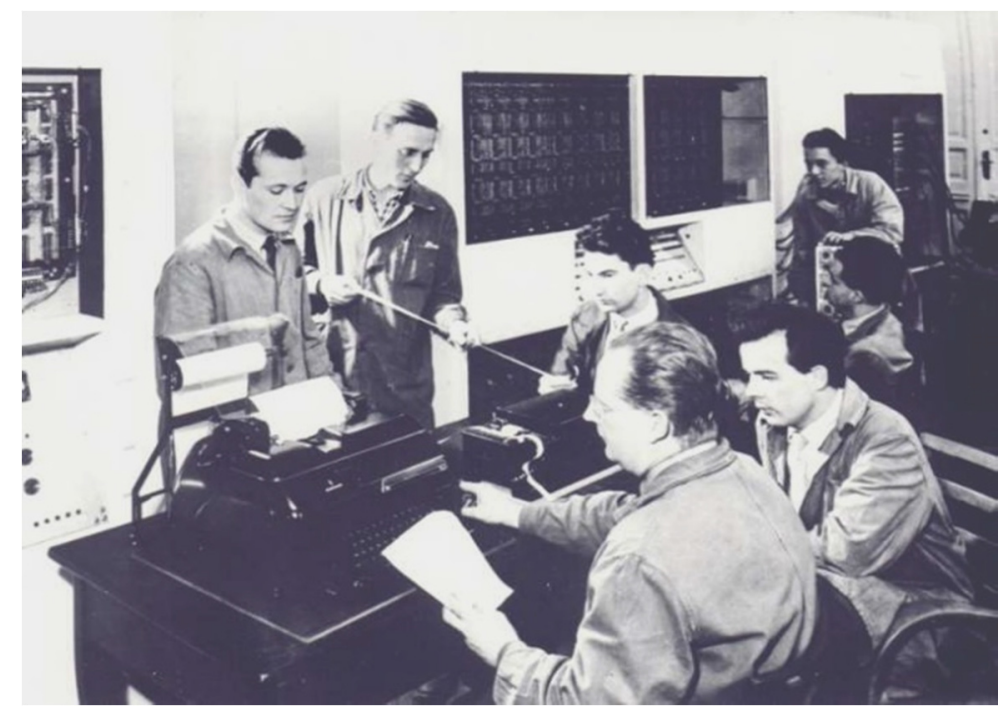

From left to right:

Sándor Podhradszki, István Ábrahám (standing) and Imre Molnár, Győző Kovács, László Szanyi (sitting).

In the back: Bálint Dömölki (sitting) and Zsolt Várkonyi (standing).

In practice, more or less reliable operation was still far away and the whole year of 1959 was spent with testing and with efforts to improve reliability. There were, however, short good periods sometimes, and a few first real applications could have been - with many difficulties - performed.

The main reason for low reliability was the error-prone operation of electronic tubes. So, the goal of the regular testing was to predict which tubes are going to fail in the next period in order to replace them before they actually did fail. One of the methods for this prediction was testing in extreme conditions (e.g. high/low voltages).

In the second half of 1960 the visit of G.P. Lopato [9], member of the team designing the M-3 (and chief engineer of the Minsk computer factory), helped the final tuning. Starting from early 1960 M-3 was in normal regular operation.

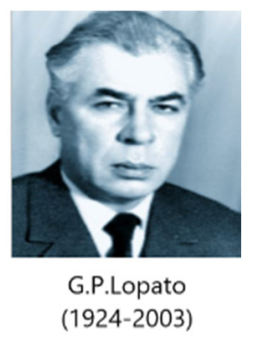

\section{Operation of the $M-3$}

Despite its low performance, M-3 was successfully used for the solution of many real-life problems both for scientific-engineering calculations (e.g. optical lenses, statics of a bridge) and in mathematical economics (e.g. balance of intersectoral relations, linear programming). When the news about the availability of the first electronic computer spread in Hungary, people from a wide range of professions brought to the KKCS their problems involving many calculations, having been performed earlier by hand or with electromechanical calculators. Some of the problems were even considered hopeless 
to solve numerically, because of the huge amount of calculations required (e.g. inversion of large matrices).

Applications in new fields started too, like e.g. linguistics (text analysis, early experiments with machine translation).

As the most important contribution of M-3 to the computer field in Hungary, its role in educating computer experts can be considered: many of the future leading personalities - both on the development and on the application side - got acquainted with computing around the M-3.

M-3 served academic computing until 1965, then it was given to Szeged University, where it was used for educational purposes until 1968.

\section{After $M-3$}

In the first part of the 60s commercial computers started to arrive in Hungary both from the USSR (Ural 1, 2) and from the West (Bull Gamma, Elliott-803, Gier). Production of computers started in the second half of the 60s, with EMG-830 and the PDP compatible - TPA series. Later, Hungary participated in the Unified System (Riad) project with its smallest model (R-10) manufactured under French license. More about the history of computing in Hungary, see in [10] and [11].

Some events to commemorate the first electronic computer in Hungary were:

- On the occasion of the $50^{\text {th }}$ anniversary of the (official) launch, a memorial session about M-3 was held at the Hungarian Museum of Science, Technology, and Transport in May 2009.

- A mini-conference, devoted to the KKCS, as the cradle of computing in Hungary was organized by the IT History Forum of the John von Neumann Computer Society in October 2014 (video recording available on YouTube, in Hungarian) [12].

- A few remaining parts of M-3 can be seen at the Information Technology History Exhibition of the John von Neumann Computer Society in the SzentGyörgyi Albert Agora, Szeged [13].

- More detailed accounts on the history of M-3 have been published in English by Győző Kovács, key person of the M-3 building team [14], [15] and by Máté Szabó, a young researcher of Hungarian IT history [16]. 


\section{References}

[1] Tibor Szentiványi: A számítástechnika kezdetei Magyarországon [The beginnings of computing in Hungary], Természet Világa, 1994, No. 6, p. 5 (in Hungarian).

[2] Б.Н. Малиновский: История вычислителной техннки в лицах. Киев, 1995, ISBN 5-7707-6131-8 [English translation: Malinovsky, Boris Nikolaevich. Pioneers of Soviet Computing. Edited by Anne Fitzpatrick. Translated by Emmanuel Aronie, N.p.: published electronically, 2010].

http://www.sigcis.org/files/sigcismc2010 001.pdf

[3] Isaac Semenovich Bruk, One of the USSR most famous computer pioneers. Russian Virtual Computer Museum, Hall of fame. http://www.computer-museum.ru/english/ galglory en/Bruk.htm

[4] Bashir Iskanderovich Rameev. Russian Virtual Computer Museum, Hall of fame. http://www.computer-museum.ru/english/galglory en/rameev.htm

[5] Automatic Digital Computer M-1. Russian Virtual Computer Museum. http://www.computer-museum.ru/english/m1.htm?sphrase id=283246

[6] The Fast Universal Digital Computer M-2. Russian Virtual Computer Museum. http://www.computer-museum.ru/english/m2.htm

[7] The M-3 computer. Russian Virtual Computer Museum. http://www.computermuseum.ru/english/m3.htm

[8] Nikolay Yakovlevich Matyukhin. Russian Virtual Computer Museum, Hall of fame. http://www.computer-museum.ru/english/galglory en/Matyukhin.htm

[9] Georgiy Pavlovich Lopato. Russian Virtual Computer Museum, Hall of fame. http://www.computer-museum.ru/english/galglory en/Lopato.htm

[10] MTA KKCS. Memorial conference about the Research Group on Cybernetics, October 15, 2014. http://itf2.njszt.hu/itf rendezvenyek/mta-kkcs

[11] Zsuzsa Szenrgyörgyi. A Short History of Computing in Hungary, Annals of the History of Computing, Vol. 21, No. 3, 1999.

http://itf2.njszt.hu/324rtr4/uploads/HUNGAR1-11.pdf

[12] Bálint Dömölki. Computing in Hungary - Through the History of Five Institutions, in: Proceedings of the 8th IT STAR Workshop on History of Computing, pp. 8093, IT STAR Publications, Volume 7, ISBN 978-88-98091-34-8.

http://itf2.njszt.hu/objektum/computing-in-hungary-through-the-history-of-fiveinstitutions

[13] The past of the future. IT History exhibition of the John von Neumann Computer Society. http://ajovomultja.hu/?language=en 
[14] Győző Kovács. The short history of M-3, the first Hungarian Electronic Digital Tube Computer, IT STAR Newsletter, Vol. 6, 2014, No. 3, pp. 4-6.

http://www.scholze-simmel.at/it star/wp-content/uploads/nl 3 08.pdf

[15] Győzö Kovács. 50 Years Ago We Constructed the First Hungarian Tube Computer, the M-3, IFIP Congress, Brisbane Australia 2010, IFIP AICT 325, pp. 68-79, New York: Springer, 2010, ISBN 9783642151.

[16] Máté Szabó. The M-3 in Budapest and Szeged (Scanning our Past). Proceedings of the IEEE, Volume 104, Issue 10, Oct. 2016, pp. 2062-2069.

http://itf2.njszt.hu/324rtr4/uploads/The M-3 in Budapest and Szeged preprint.pdf 